\title{
Cowden Syndrome: report of a case and brief review of literature
}

\author{
Síndrome de Cowden : Relato de caso e uma breve revisão da literatura
}

Ana Carolina Souza Porto ${ }^{1}$

Elisabeth Roider ${ }^{1}$

Thomas Ruzicka

DOI: http://dx.doi.org/10.1590/abd1806-4841.20132578

\begin{abstract}
We present the case of a female patient with facial cutaneous lesions, a cobblestone-like pattern of the oral mucosa, and verruciform lesions on the hand since her youth. She reported a history of breast cancer, endometrial cancer, melanoma and multiple benign tumors and cysts. PTEN gene analysis was performed and confirmed Cowden Syndrome, a rare genodermatosis with an autosomal dominant pattern of inheritance, characterized by multiple hamartomas. The phosphatase and tensin homolog (PTEN) gene negatively regulates cell proliferation and cell cycle progression. Loss of PTEN function contributes to an increased risk of cancer. We emphasize the importance of early detection and accurate management of Cowden Syndrome.
\end{abstract}

Keywords: Breast neoplasms; Genes, neoplasm; Hamartoma syndrome, multiple

Resumo: Apresentamos o caso de uma paciente com lesões cutâneas faciais, mucosa oral com aparência de paralelepípedo, e lesões de aspecto verrucoso na mão desde a sua juventude. Ela relatou uma história de câncer de mama, câncer de endométrio, melanoma e múltiplos tumores benignos e cistos. A análise genética PTEN foi realizada e confirmou a Síndrome de Cowden, uma genodermatose rara, com um padrão de herança autossômica dominante, caracterizada por múltiplos hamartomas. O gene homólogo de fosfatase e angiotensina (PTEN) regula negativamente a proliferação celular e a progressão do ciclo celular. A perda da função PTEN contribui para um aumento do risco de câncer. Ressaltamos a importância da detecção precoce e tratamento preciso da Síndrome de Cowden.

Palavras-chave: Genes neoplásicos; Neoplasias da mama; Síndrome do hamartoma múltiplo

\section{INTRODUCTION}

Cowden syndrome (CS), also known as multiple hamartoma syndrome, is a rare genodermatosis with an autosomal dominant pattern of inheritance. ${ }^{1}$ CS is the best described PTEN hamartoma tumor syndrome (PHTS). PHTS is a group of disorders that have in common a disorganized growth of native cells in native tissues and includes CS, Bannayan-Riley-Ruvalcaba syndrome (BRRS), Lhermitte-Duclos disease (LDD), Proteus and Proteus-like syndrome. ${ }^{2}$ CS is the only PHTS disorder associated with a documented predisposition to malignancies. ${ }^{1}$ Early diagnosis of CS is difficult due to the highly variable expressivity of signs and symptoms, in addition to the rarity of the disease..$^{1,2,3}$

\section{CASE REPORT}

A 59-year-old female patient presented with a lifelong history of carcinoma and unclear cutaneous and mucocutaneous lesions. Clinical investigation showed firm, flat-topped, yellowish papules in the

\footnotetext{
Received on 27.02.2013.

Approved by the Advisory Board and accepted for publication on 02.05.2013

* Work performed at the Department of Dermatology and Allergy, Ludwig-Maximilian University - Munich, Germany.

Conflict of interest: None

Financial Support: None

Residents in Dermatology - Medical Department of Dermatology and Allergy, Ludwig-Maximilian University of Munich, Germany.

Director of the Department of Dermatology and Allergy, Ludwig-Maximilian University of Munich, Germany.

C2013 by Anais Brasileiros de Dermatologia
} 
periorbital region and tiny whitish papules of the oral mucosa (Figure 1). Multiple hyperkeratotic verruciform lesions on the back of the hand and palmar pits were found (Figure 2). A macrocephaly above the $97^{\text {th }}$ percentile was diagnosed. The patient's history included breast cancer at the age of 34, an endometrial carcinoma at age 46 and a recently diagnosed malignant melanoma. Furthermore, the patient reported adenomas of thyroid, recurrent gastrointestinal polyps and cutaneous lipomas and trichilemmomas. She also suffered from kidney cysts, cysts of the fallopian tube, cataract, osteoporosis and diffuse hair loss. Her family history showed no incidence of multiple hamartoma syndrome.

Laboratory testing and organ examination did not show any pathologic findings. Histology of one periorbital lesion showed a symmetrical epithelial nodular proliferation with mild papillomatosis, overlying hiperkeratosis and downgrowth of epithelial cells with clear cell differentiation. Histology of one back-of-hand lesion showed regular ortho-and hyperkeratosis (Figures 3 and 4). Genetic analysis finally confirmed heterozygous deletion of nucleotide 968 in exon 8 of the PTEN gene, located on chromosome 10.

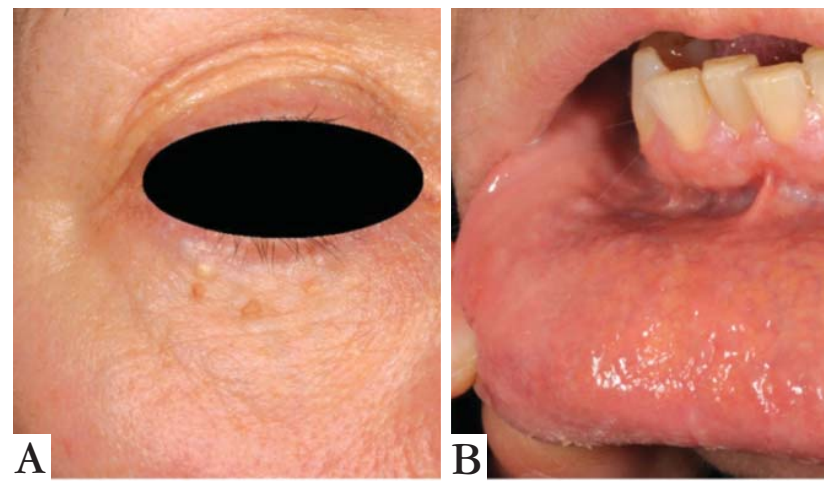

FIGURE 1: A. Small yellowish papules of flat top around the eye. B. Papular lesions on the lips with characteristic cobblestone-like pattern

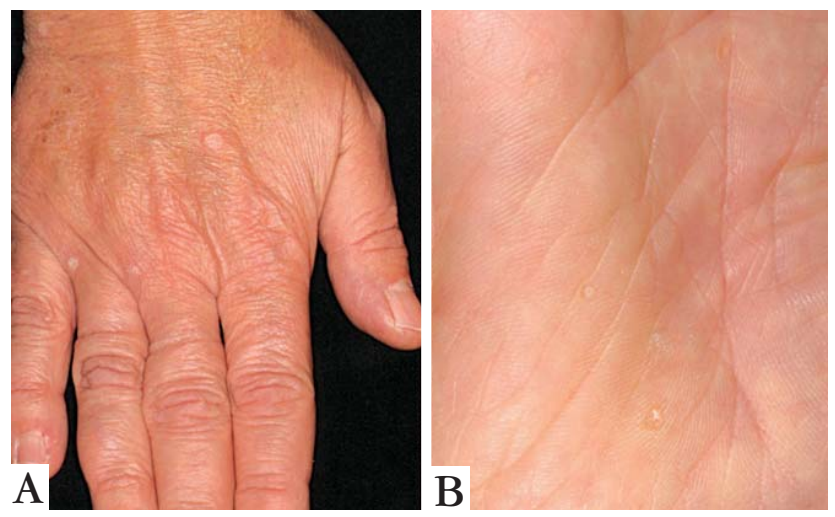

FIgURe 2: A. Acral hyperkeratoses. B. Palmar pits

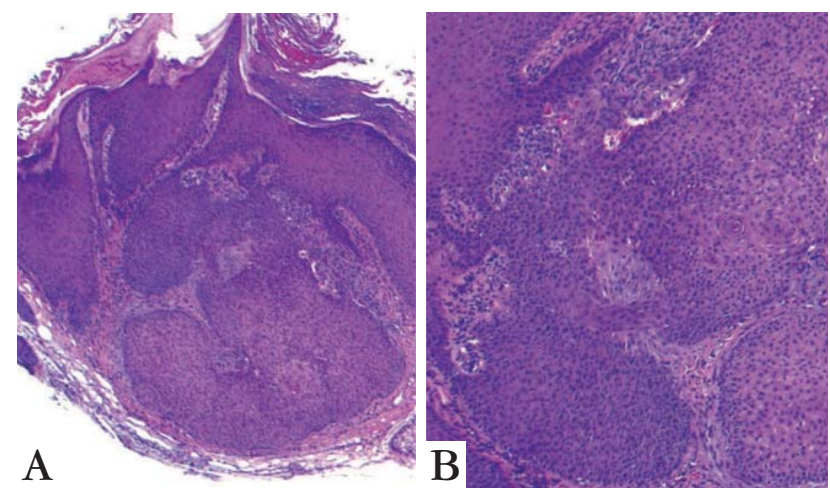

FIGURE 3: Skin biopsy of the periorbital region showed a nodular proliferation with papillomatosis, overlying hyperkeratosis and downgrowth of epithelial cells presenting a tricholemmoma

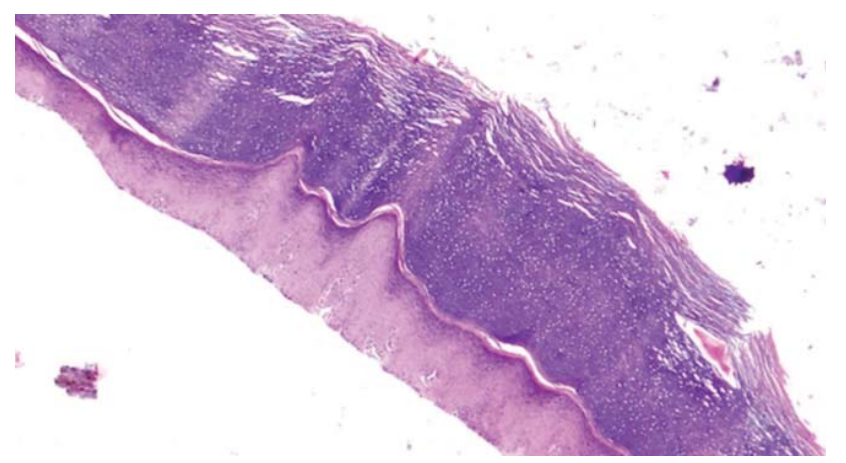

FIGURE 4: Skin biopsy of one back-of-hand lesion showed regular ortho-and hyperkeratosis

\section{DISCUSSION}

CS, also known as multiple hamartoma syndrome, was first described in 1963 by Lloyd and Dennis, referring to their patient Rachael Cowden. ${ }^{1,4}$ This syndrome is a genetic disorder characterized by a broad range of symptoms and signs, including multiple cutaneous/mucocutaneous lesions and involvement of different organs, leading to a massive cumulative lifetime risk of cancer. ${ }^{2,3,4}$ Although data is limited, the estimated prevalence of CS is $1 / 200,000{ }^{1,3,4}$ However, the true prevalence may be greater because many of the CS features occur also in the general population. ${ }^{1}$ Both sexes can be affected, although a slight female predominance has been observed. CS is most often diagnosed during the third decade of life. The age of onset may however vary from 4 to 75 years. ${ }^{4,5}$

Most patients with CS have a germ-line mutation in the tumor suppressor gene phosphatase and tensin homologue (PTEN), located on chromosome 10q23. The PTEN tumor suppressor gene encodes a phosphatase, which is a negative regulator of PI3KAKT and mTOR signaling pathways, and controls cell proliferation, cell cycle progression, and apoptosis. $^{2,6}$ The loss of PTEN function contributes to 
cellular transformation and increases the risk of cancer development in many organs. More than 100 different germline mutations of the PTEN have been reported, but no significant correlation has been found between the specific mutation type and the occurrence of different types of cancer or non-malignant clinical features. ${ }^{2}$ In addition, $20 \%$ of CS patients have no identifiable mutation. ${ }^{3,7}$

Although expression of the disease is variable, cutaneous lesions are common and pathognomonic. ${ }^{5,7}$ Usually these lesions are the first signal in CS patients and therefore may serve as first clue for early diagnosis before severe malignancies develop. ${ }^{8,9}$ In over $90 \%$ of CS patients pathognomonic cutaneous lesions such as trichilemmomas, acral keratoses, pits on the palms and soles, and papular lesions on the lips and oral mucosa with a characteristic cobblestone-like pattern develop. ${ }^{7.8}$ Lipomas are also a common finding in CS. All of these lesions were found in the case described in this report.

The most frequently reported extracutaneous manifestation of CS is thyroid disease, which occurs in up to $75 \%$ of cases. ${ }^{1,4,8}$ This may manifest as benign multinodular goiter, lymphocytic thyreoiditis, adenomas or thyroid dysfunction. Thyroid cancer occurs in 3 to $10 \%$ of patients and represents the second most common cancer in CS. ${ }^{1,9,10}$ These cancers are exclusively of a follicular or papillary type. ${ }^{10}$

Breast lesions occur in almost $75 \%$ of all women suffering from CS and usually manifest as fibrocystic disease. ${ }^{4,8}$ Breast cancer is the most common malignancy of CS and the most important cause of death, leading to a cumulated risk of $77 \%$ at the age of $70 .^{2}$

Macrocephaly is a common finding in CS patients, present in approximately $80 \%$ of patients with CS. ${ }^{1}$ Polyps of the gastrointestinal tract occur in at least $50 \%$ of CS patients, leading to an increased risk for colorectal cancer. ${ }^{1,4,6}$ Endometrial cancer occurs in $5 \%$ to $10 \%$ of all women with CS. ${ }^{10}$ Other common findings include benign ovarian cysts, neurologic malformations, mental retardation and an immune dysfunction. Interestingly, a recent study showed a melanoma prevalence of $6 \%$ in CS patients. ${ }^{2}$

The diagnosis of CS is eminently clinical, based on criteria proposed by the International Cowden Syndrome Consortium (Chart 1). ${ }^{1}$ As can be seen in chart 1 , our patient presented multiple pathognomonic lesions and major and minor criteria.

Management of Cowden Syndrome includes early detection of malignant conditions, patient education, genetic counseling, and regular surveillance. ${ }^{6}$ Given the high risk of malignancy, cancer surveillance is the major focus of medical management. The National Comprehensive Cancer Network
(NCCN) provides regularly updated guidelines that outline a cancer surveillance program for men and women with Cowden Syndrome (Chart 2). ${ }^{1,9}$

CHART 1: Diagnostic criteria proposed by the International Cowden Syndrome Consortium (ICSC). (Underlined criteria are presented by the patient)

Diagnostic criteria proposed by the International Cowden Syndrome Consortium (ICSC)

Pathognomonic lesions

(1 required)

- Six or more facial papules ( $\geq 3$ trichilemmomas)

- Facial cutaneous papules + papillomatosis of the oral mucosa

- Papillomatosis of the oral mucosa + acral keratosis

- $\geq 6$ palmoplantar keratoses

Major criteria

(2 required, one must be macrocephaly or Lhermitte-Duclos disease)

- Breast carcinoma

- Thyroid carcinoma

- Macrocephaly (>97\%)

- Lhermitte-Duclos disease

- Endometrial carcinoma

Minor criteria

(4 required)

- Thyroid lesions (other than carcinoma)

- Learning difficulties or delayed development

- Gastrointestinal hamartomas

- Lipomas

- Fibromas

- Fibrocystic disease of the breast

- Genitourinary malformations or carcinoma

One major criterion and three minor criteria may also indicate a diagnosis of Cowden Syndrome

Adapted from: Mukamal LV, et al. ${ }^{9}$

CHART 2: Management of Cowden Syndrome

Management of Cowden Syndrome

Women

- Breast self-examination starting at age 18 .

- Clinical breast exam starting at age 25 or 5-10 years before the earliest breast cancer in the family occurred.

- Patient education about endometrial cancer symptoms and clinical screening.

- Discussion of prophylactic mastectomy and hysterectomy.

Men and women

- Annual physical examination starting at age 18 or 5 years before the youngest age of cancer in family history.

- Thyroid ultrasound at age 18 , then once a year.

- Colonoscopy, starting at the age of 35, then every 5 to 10 years.

- Annual dermatologic exam.

Risk to relatives

- Explain possible inherited cancer risks to relatives, options for risk assessment and management.

- Provide genetic counseling.

Adapted from: The National Comprehensive Cancer Network (NCCN). 
All in all, it would appear that a large gap exists between the estimated prevalence and the actual diagnosed number of patients with CS. We hope that this report will serve to emphasize the importance of careful clinical investigation, so that appropriate surveillance and risk management actions can be taken for the benefit of these patients. Our patient reached 59 before being diagnosed with CS.

\section{REFERENCES}

1. The National Comprehensive Cancer Network (NCCN). Clinical Practice Guidelines in Oncology. Genetic/Familial High-Risk Assessment: Breast and Ovarian Cancer. Version 1.2012. New York: NCCN; 2012.

2. Bubien V, Bonnet F, Brouste V, Hoppe S, Barouk-Simonet E, David A, et al. High cumulative risks of cancer in patients with PTEN hamartoma tumour syndrome. J Med Genet. 2013;50:255-63.

3. Melbârde-Gorkuðða I, Irmejs A, Bçrziòa D, Strumfa I, Aboliòð A, Gardovskis A, et al. Challenges in the management of a patient with Cowden Syndrome: case report and literature review. Hered Cancer Clin Pract. 2012;10:5.

4. Hammami S, Berriche 0, Ali HB, Hellara 0, Ansar F, Mahjoub S. Managing the risk of cancer in Cowden Syndrome: a case report. J Med Case Rep. 2012;6:225.

5. Masmoudi A, Chermi ZM, Marrekchi S, Raida BS, Boudaya S, Mseddi M, et al. Cowden Syndrome. J Dermatol Case Rep. 2011;5:8-13.

6. Tutluer S, Tanriover MD, Guven GS. Cowden Syndrome: a major indication for extensive cancer surveillance. Med Oncol. 2012;29:1365-8.

7. Amer M, Mostafa FF, Attwa EM, Ibrahim S. Cowden's Syndrome: a clinical, immunological, and histopathological study. Int J Dermatol. 2011;50:516-21.

8. Kovich 0, Cohen D. Cowden's Syndrome. Dermatol Online J. 2004:10:3

9. Mukamal LV, Ferreira AF, Jacques Cde M, Amorim CA, Pineiro-Maceira J, Ramose-Silva M. Cowden Syndrome: review and report of a case of late diagnosis. Int $J$ Dermatol. 2012;51:1494-9.

10. Pilarski R. Cowden Syndrome: a critical review of the clinical literature. J Genet Couns. 2009;18:13-27.

MAILING ADDRESS:

Ana Carolina Souza Porto

Rua Loegreen, 1654 - Apt. 71

04040-002 - Sao Paulo - SP

Brazil

E-mail: carolsporto1@hotmail.com

How to cite this article: Porto ACS, Roider E, Ruzicka T. Report of a case of Cowden Syndrome: report of a case and brief review of the literature. An Bras Dermatol. 2013;88(6 Suppl 1):S52-5. 